ISSN: 1907-9931 (print), 2476-9991 (online)

\title{
KARAKTERISTIK OSEANOGRAFI FISIK (BATIMETRI, PASANG SURUT, GELOMBANG SIGNIFIKAN DAN ARUS LAUT) PERAIRAN TELUK BUNGUS
}

\section{CHARACTERISTICS OF PHYSICAL OCEANOGRAPHY (BATHYMETRY, TIDE, WAVE SIGNIFICANT HEIGHT AND SEA CURRRENT) IN BUNGUS BAY}

\author{
Try Al Tanto ${ }^{1 *}$, Semeidi Husrin ${ }^{1}$, Ulung Jantama Wisha1, Aprizon Putra1, Radha Karina \\ Putri $^{2}$, Ilham 1 \\ ${ }^{1}$ Loka Penelitian Sumber Daya dan Kerentanan Pesisir, Balitbang KP-KKP Jl. Raya Padang- \\ Painan Km.16, Padang \\ ${ }^{2} J u r u s a n$ Oseanografi Universitas Diponogoro \\ *Corresponding author e-mail: try.altanto@gmail.com
}

Submitted: 14 Maret 2016 / Revised: 19 Mei 2016 / Accepted: 29 Oktober 2016

DOI: http://dx.doi.org/10.21107/jk.v9i2.1240

\begin{abstract}
Bungus bay waters have a lot of activity, but there is no reliable data related to their oceanographic parameters. It is necessary to study their physical oceanography, to acquire basic information of physical oceanographic characteristics that are useful for the daily activities around these waters. Bathymetric data obtained from the map issued by Dishidros, analyzed in the form of $2 D$ and $3 D$ map display. Tide data measured from ADCP measuring devices, a measuring instrument for the major ocean currents, and also HOBO which has a pressure sensor in the device. While the wave data obtained from ECMWF in the form of significant wave height, but it also contained model / forecasting a significant wave height of BMKG. The depth of the bay of Bungus relatively shallow sea, which reaches $30 \mathrm{~m}$. Form of the sea bottom relief not seen a significant impact on the influence of the ocean, because the waters are adequately protected by the shape of the bay. Tide that occur is predominantly a mixture of type double, $139.30 \mathrm{~cm}$ (October-November 2013). Significant wave Bungus bay waters and surrounding areas (JanuaryOctober 2013) is 0.42 to $1.7 \mathrm{~m}$ and 0.3 to $2.5 \mathrm{~m}$ (August-December 2015). Largest wave height occurs mainly dated October 9, 2013 until October 11, 2013 is 1.5-1.7 m, and 8 to 14 September 2015 to reach $2.25 \mathrm{~m}$. Currents in Bungus bay waters generally dominated by the influence of zonal flows, both the depth current of $10.5 \mathrm{~m}$ and $18.5 \mathrm{~m}$. The average velocity of depth current of $10.5 \mathrm{~m}$ by $0.0477 \mathrm{~m} / \mathrm{s}$, but there was a large current $0.5240 \mathrm{~m} / \mathrm{sec}$ November 11, 2013 at 14:50 am with the South-East direction. At a depth of $18.5 \mathrm{~m}$, the average current velocity $0.3799 \mathrm{~m} / \mathrm{s}$ and a maximum current of $0.9320 \mathrm{~m} / \mathrm{s}$ on 14 November 2013 at 22:00 pm at South West direction.
\end{abstract}

Keywords: Bathymetry, Tidal, Wave, Current, Bungus Bay

\begin{abstract}
ABSTRAK
Perairan Teluk Bungus berlangsung cukup banyak aktivitas, namun belum ada data-data valid berkaitan dengan parameter oseanografi perairannya. Perlu dilakukan kajian oseanografi fisik, sehingga diperoleh informasi dasar karakteristik oseanografi fisik yang berguna untuk kelancaran aktifitas di sekitar perairan ini. Data batimetri diperoleh dari peta yang dikeluarkan oleh Dishidros, dianalisis berupa tampilan peta 2D dan 3D. Data pasang surut air laut terukur dari alat ukur $A D C P$, merupakan alat ukur utama untuk arus laut, dan juga HOBO yang memiliki sensor tekanan dalam perangkatnya. Sedangkan data gelombang diperoleh dari ECMWF berupa tinggi gelombang signifikan, selain itu juga terdapat model/peramalan tinggi gelombang signifikan dari BMKG. Kedalaman laut Teluk Bungus tergolong dangkal, yaitu mencapai $30 \mathrm{~m}$. Bentuk relief dasar lautnya tidak terlihat dampak signifikan dari pengaruh samudera, karena perairan cukup
\end{abstract}


terlindungi oleh bentuk teluk. Pasang surut yang terjadi adalah tipe campuran dominan ganda, tunggang pasut sebesar 139,30 cm (Oktober - November 2013). Gelombang signifikan perairanTeluk Bungus dan sekitarnya (Januari - Oktober 2013) adalah 0,42-1,7 m dan 0,3-2,5 m (Agustus - Desember 2015). Tinggi gelombang cukup besar terjadi terutama tanggal 9 Oktober 2013 hingga 11 Oktober 2013 yaitu 1,5-1,7 m, serta 8 - 14 September 2015 hingga mencapai 2,25 m. Arus laut perairan Teluk Bungus umumnya didominasi oleh pengaruh arus zonal, baik arus kedalaman 10,5 m maupun arus pada kedalaman 18,5 m. Kecepatan rata-rata arus kedalaman 10,5 m sebesar 0,0477 m/dt, namun terjadi arus cukup besar 0,5240 m/dt tanggal 11 November 2013 pukul 14.50 WIB dengan arah Tenggara-Selatan. Pada kedalaman 18,5 m, kecepatan arus rata-rata 0,3799 $\mathrm{m} / \mathrm{dt}$ dan arus maksimum 0,9320 m/dt tanggal 14 November 2013 pukul 22.00 WIB dengan arah Barat Daya.

Kata Kunci: Bathymetri, Pasang Surut, Gelombang Signifikan, Arus Laut, Perairan Teluk Bungus

\section{PENDAHULUAN}

Oseanografi merupakan studi atau ilmu yang mempelajari tentang lautan, salah satunya berkaitan dengan parameter fisik di laut. Oseanografi fisik adalah studi tentang sifat fisik dan dinamika lautan (Stewart, 2008). Ruang lingkup dari parameter oseanografi fisik cukup banyak dan akan selalu mengalami perkembangan. Dalam hal ini hanya dibahas beberapa parameter yang terkait dengan dinamika pesisir berupa batimetri, pasang surut, gelombang signifikan dan arus laut yang terjadi pada perairan Teluk Bungus dan sekitarnya. Parameter-parameter tersebut dapat berguna nantinya dalam berbagai aktivitas yang terjadi di sekitar perairan Teluk Bungus. Data batimetri dan pasang surut berguna dalam alur perlayaran kapal, yang mana terdapat lokasi-lokasi (topografi) di laut yang memiliki kedalaman rendah, ditambah saat kondisi air surut tentunya lokasi tersebut akan berakibat fatal jika tetap dilalui oleh kapal (karam). Selain itu, untuk kondisi pasang surut juga berguna sebagai pemantauan tsunami, badai pasang, navigasi kapal, olah raga perairan, rekayasa pantai dan pengelolaan pantai (Bakosurtanal, 2007). Data gelombang berguna saat akan melakukan perlayaran, untuk menjaga kondisi aman dalam perlayaran dan waktu-waktu tidak disarankan untuk berlayar.

Perairan Teluk Bungus berhadapan langsung dengan Samudera Hindia, merupakan wilayah administrasi dari Kecamatan Bungus - Teluk Kabung, Kota Padang (Yulius et al., 2010). Pada wilayah perairan ini berlangsung cukup banyak aktivitas, diantaranya pelabuhan penyeberangan, pelabuhan perikanan untuk pendaratan ikan, aktivitas kapal pertamina dan pengangkutan batubara untuk keperluan PLTU. Selain itu juga terdapat budidaya perikanan dan pariwisata pantai yang cukup ramai. Dengan kondisi tersebut, sudah semestinya diperlukan informasi dasar berkaitan dengan dinamika pantai (oseanografi fisik), yang penting untuk keamanan aktivitas yang ada tersebut.

Tujuan penelitian ini adalah menentukan karakteristik oseanografi fisik dari perairan Teluk Bungus berupa batimetri (profil kedalaman perairan), kondisi pasang surut, gelombang signifikan dan arus laut. Kajian oseanografi berupa dinamika pesisir pada perairan ini cukup penting terutama untuk keselamatan kapal-kapal yang melaluinya (Bakosurtanal, 2007). Ditambah lagi dengan belum ada data-data valid berkenaan dengan parameter oseanografi perairan Teluk Bungus. Dengan informasi dasar beberapa parameter oseanografi fisik tersebut diharapkan dapat berguna bagi pemegang kepentingan di kawasan ini, juga masyarakat yang berkativitas di sekitarnya.

\section{MATERI DAN METODE}

Kegiatan penelitian dilaksanakan pada perairan Teluk Bungus - Kota Padang dan sekitarnya. Penelitian ini termasuk dalam penelitian kuantitatif, menggunakan metode pengambilan data dengan pengukuran langsung di lapangan dan juga menggunakan data sekunder berupa hasil model/peramalan dan juga pengukuran yang dilakukan pihak lain. Survei lapang dilakukan untuk pengukuran data arus laut dengan menggunakan alat ukur ADCP yang juga memiliki sensor tekanan pada 
perangkatnya, sehingga juga diperoleh data pasang surut laut. Kegiatan survei lapang terlaksana pada awal Bulan Oktober dan November Tahun 2013, dengan lokasi di sekitar Pulau Kasiak - Teluk Bungus.

Arus laut (sea current) merupakan gerakan massa air laut dari satu tempat menuju tempat lain secara vertikal (gerakan ke atas) atau secara horizontal (gerakan ke samping) secara terus menerus hingga menuju kestabilan (Pond \& Pickard, 1993 dalam Samskerta, I Putu, Huda Bachtiar, Fitri Riandini, 2011). Di perairan dangkal (kawasan pantai), arus laut dapat dibangkitkan oleh gelombang laut, pasut laut atau sampai tingkat tertentu angin. Di dekat khatulistiwa, angin pasat (trade wind) menggerakkan permukaan air ke arah barat. Sementara itu, di daerah lintang sedang (temperate), angin barat (westerlies wind) menggerakan kembali permukaan air ke timur (http://www.balipost.co.id). Pengukuran data arus laut dilakukan dengan menggunakan alat ukur ADCP dengan metode euler. Perekaman data arus dilakukan hampir selama dua bulan, pemasangan alat ukur pada awal Bulan Oktober 2013 dan pengangkatan terlaksana pada akhir bulan November 2013. Analisis arus laut yang dilakukan adalah spectral analysis dengan menggunakan software Statistica 7 , untuk melihat pola arus yang terjadi dan periode dominan dalam rentang waktu pengukuran tersebut. Dalam hal ini arus yang dianalisis adalah arus pada kedalaman $10.5 \mathrm{~m}$ yang masih mewakili untuk arus permukaan dan arus kedalaman $18.5 \mathrm{~m}$. Dengan analisis ini akan terlihat perbedaan dari kedua arus laut yang terjadi pada kedalaman berbeda tersebut.

Batimetri merupakan ukuran tinggi rendahnya dasar laut, dimana peta bathymetri memberikan infomasi mengenai dasar laut (Nurjaya, 1991 dalam Ariana K, 2002). Data batimetri perairan Teluk Bungus dan sekitarnya diperoleh dari peta yang dikeluarkan oleh Dishidros. Peta tersebut diperbarui oleh Jawatan Hidro-Oseanografi Tahun 2006, dan koreksi terakhir Tahun 2011. Selain itu, data batimetri juga diperoleh dari pengukuran lapang menggunakan alat echosounder dan GPS pada Tahun 2008 oleh Yulius dkk. Pengolahan peta batimetri dilakukan menggunakan perangkat lunak pengolah data Golden Software Surfer. Selain hasil tampilan peta $2 D$ yang biasa dalam pengolahan parameter oseanografi, hasil pengolahan peta batimetri juga ditampilkan berupa peta $3 D$, sehingga dapat terlihat topografi dasar perairan daerah studi.

Pasang surut air laut timbul terutama karena gaya tarik menarik gravitasi bumi terhadap bulan dan matahari, sedang kontribusi gaya tarik menarik planet-planet lainnya kecil. Besar naik turunnya permukaan laut tergantung pada kedudukan bumi terhadap bulan dan matahari. Pemahaman akan jenis pasang surut dengan mengetahui pola terjadinya pasang dan surut sangat penting untuk berbagai aplikasi, seperti untuk navigasi, rekayasa pantai (pembuatan pelabuhan, bangunan penahan gelombang, jembatan laut, dan pemasangan pipa bawah laut) (Modifikasi dari Pugh, 1987 dalam Sudjono et al., 2011), dan lain-lainnya. Data pasang surut perairan Teluk Bungus diperoleh langsung dari pengukuran oleh alat pengukur arus ADCP yang memiliki sensor tekanan dalam perangkatnya. Nilai kedalaman yang diperoleh tersebut sesuai dengan hasil pengukuran lapang, dilakukan proses filtering data berupa pengolahan data kedalaman menjadi tinggi muka air berdasarkan nilai surut terendah selama waktu pengukuran. Penentuan jenis pasang surut dapat diketahui dengan melihat pola terjadinya pasang dan surut. Penentuan jenis pasang surut lainnya yang paling sederhana adalah secara numeris dengan menggunakan periode dominan dari pasang surut yang diamati. Hal ini didasarkan pada bilangan Formzahl (F), yaitu perbandingan jumlah amplitudo dua komponen diurnal utama $\left(A_{K 1}\right.$ dan $\left.A_{O 1}\right)$ terhadap jumlah amplitudo dua komponen semi-diurnal utama $\left(A_{M 2}\right.$ dan $\left.A_{S 2}\right)$. Hal ini tertuang dalam tulisan Wyrki yang menyebutkan bahwa Empat pasang parsial yang paling penting, $\mathrm{M} 2, \mathrm{~S} 2, \mathrm{~K} 1$ and $\mathrm{O} 1$ memberikan gambaran yang relatif lengkap pola pasang surut, sehingga representasinya cukup untuk informasi Umum. Komponen pasang surut tersebut diperoleh dari analisis admiralty yang dibuat dari modifikasi modul pasut (Silalahi dalam www.academia.edu dan tulisan Fadilah et al., 2014). Persamaan bilangan Formzahl adalah:

$$
F=\frac{A_{K_{1}}+A_{O_{1}}}{A_{M_{2}}+A_{S_{2}}}
$$


Klasifikasi karakteristik pasang surut berdasarkan nilai bilangan Formzahl (Bakosurtanal, 2007):

$0<F<0.25 \quad$ : semi diurnal, dimana dalam sehari terjadi dua kali pasang dan dua kali surut dengan bentuk gelombang simetris.

\section{$0.25 \leq F<1.5 \quad$ : campuran condong}

semi diurnal, dalam sehari terjadi dua kali pasang dan dua kali surut. bentuk gelombang pasang pertama tidak sama dengan gelombang pasang kedua (asimetris) dengan bentuk condong semi diurnal.

$1.5 \leq F \leq 3.0 \quad$ : campuran condong diurnal, dalam sehari terjadi dua kali pasang dan dua kali surut. Bentuk gelombang pasang pertama tidak sama dengan gelombang pasang kedua dengan bentuk condong diurnal.

$F>3.0 \quad$ : diurnal, dalam sehari terjadi sekali pasang dan sekali surut.

Selain analisis admiralty, juga dilakukan perhitungan untuk elevasi penting kondisi muka air. Diantaranya elevasi penting kondisi muka air yang ditampilkan (Tanto, 2009) adalah tinggi muka laut rata-rata $(M S L)$, tinggi muka laut pasang primer, tinggi muka laut pasang sekunder, tinggi muka laut surut primer, dan tinggi muka laut surut sekunder. Dengan penentuan elevasi penting muka air ini, dapat terlihat dengan jelas tinggi muka air tiap hari kejadian pasang dan surut di perairan Teluk Bungus. Sehingga dapat menentukan kapan terjadinya pasang purnama dan pasang perbani di sekitar perairan. Tinggi muka laut rata-rata adalah nilai rata-rata perhitungan perubahan paras laut yang terekam pada suatu periode waktu tertentu. Tinggi muka laut pasang primer adalah muka air tertinggi dari dua tinggi muka laut pasang harian pada suatu periode waktu tertentu. Artinya akan ditentukan semua nilai tinggi muka laut pasang yang diperoleh selama pengukuran. Tinggi muka laut pasang sekunder adalah muka air terendah dari dua tinggi muka laut pasang harian, yang mana nilainya lebih rendah dari air pasang primer dalam satu hari. Hal ini tidak akan terjadi untuk pasang surut harian tunggal. Tinggi muka laut surut primer adalah muka air terendah dari dua muka laut surut harian pada suatu periode waktu tertentu. Serta, tinggi muka laut surut sekunder adalah muka air tertinggi dari dua muka air surut harian, yang mana nilainya lebih tinggi dari air surut primer dalam satu hari (Tanto, 2009). Selain itu juga ditentukan elevasi penting muka air lainnya, yaitu HWL (Highest Water Level), MHHWL (Mean Higher High Water Level), MHWL (Mean High Water Level), MLWL (Mean Low Water Level), MLLWL (Mean Lower Low Water Level), dan LWL (Lowest Water Level) (https://tidesandcurrents.noaa.gov).

Gelombang laut adalah pergerakan naik dan turunnya air laut dengan arah tegak lurus pemukaan air laut yang membentuk kurva/grafik sinusoidal (Holthuijsen L.H., 2007 dalam Kurniawan dkk, 2011). Gelombang laut pada kawasan pesisir umumnya dibangkitkan di laut lepas sebagai akibat interaksi antara angin dan permukaan laut. Gelombang biasanya mendekati pantai dengan kedudukan yang membentuk sudut terhadap garis pantai sedemikian rupa, sehingga gelombang menjadi agen pembangkit arus sejajar pantai (longshore current) sebagai akibat dari pengangkutan massa air ke badan pantai (Poerbandono, 2004). Data gelombang yang ada hanya dalam bentuk tinggi gelombang signifikan, diperoleh dari ECMWF (European Centre for Medium-Range Weather Forecasts) pada lokasi area sekitar $1^{\circ} 0^{\prime} 0.00^{\prime \prime}-1^{\circ} 7^{\prime} 30.00^{\prime \prime}$ LS dan $100^{\circ} 15^{\prime} 0.00^{\prime \prime}$ - $100^{\circ} 22^{\prime} 30.00^{\prime \prime}$ BT. Data gelombang ini tersedia dengan interval waktu perekaman selama 6 jam, dan dianalisis untuk menentukan kisaran gelombang dan tinggi gelombang maksimum yang terjadi selama rentang waktu tersebut. Selain itu juga diperoleh data peramalan/model tinggi gelombang signifikan di sekitar perairan Sumatera Barat untuk rentang waktu Bulan Agustus sampai Desember 2015 (BMKG, 2015). Dengan analisis gelombang ini diharapkan bermanfaat bagi alur perlayaran di perairan Teluk Bungus dan sekitarnya, baik perlayaran menuju maupun keluar dari Teluk Bungus.

\section{HASIL DAN PEMBAHASAN}

\section{Batimetri}

Perairan Teluk Bungus memiliki kedalaman perairan mencapai $30 \mathrm{~m}$, dapat dilihat dari peta batimetri yang dihasilkan dari pengolahan datanya berikut (Gambar 1). Kedalaman laut disekitar Teluk Bungus masih tergolong dangkal (kurang dari $50 \mathrm{~m}$ ). 
Pola batimetri (Gambar 1) yang ada memperlihatkan morfologi dasar lautnya mengikuti garis pantai. Selain itu, daerah Teluk Bungus - Sumatera Barat dengan posisi geotektonik, merupakan wilayah pertemuan indo-australia plate dan eurasian plate. Hal ini menyebabkan daerah ini termasuk rawan dari gempa. Posisi Kawasan Teluk Bungus yang terletak pada jalur tektonik tersebut tentunya juga memberi pengaruh yang cukup besar terhadap morfologi dasar lautnya.

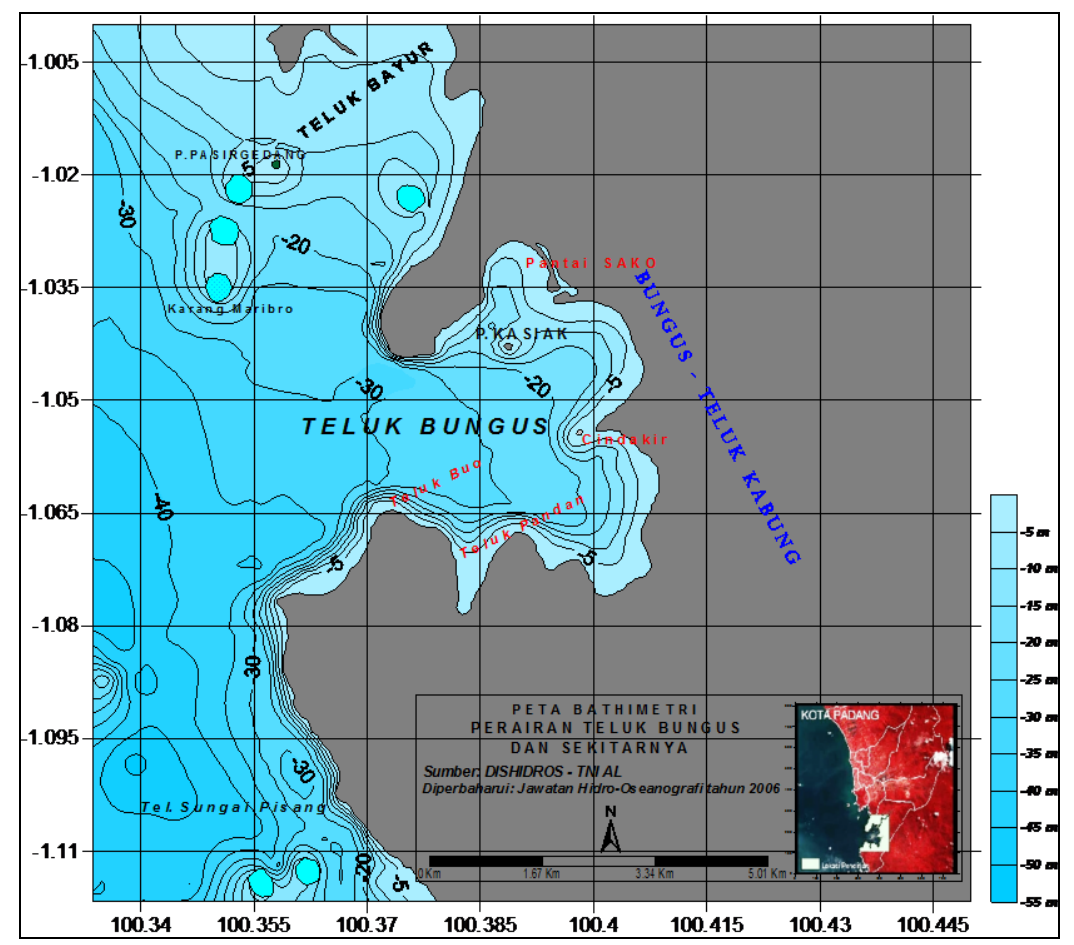

Gambar 1. Peta batimetri perairan Teluk Bungus dan sekitarnya
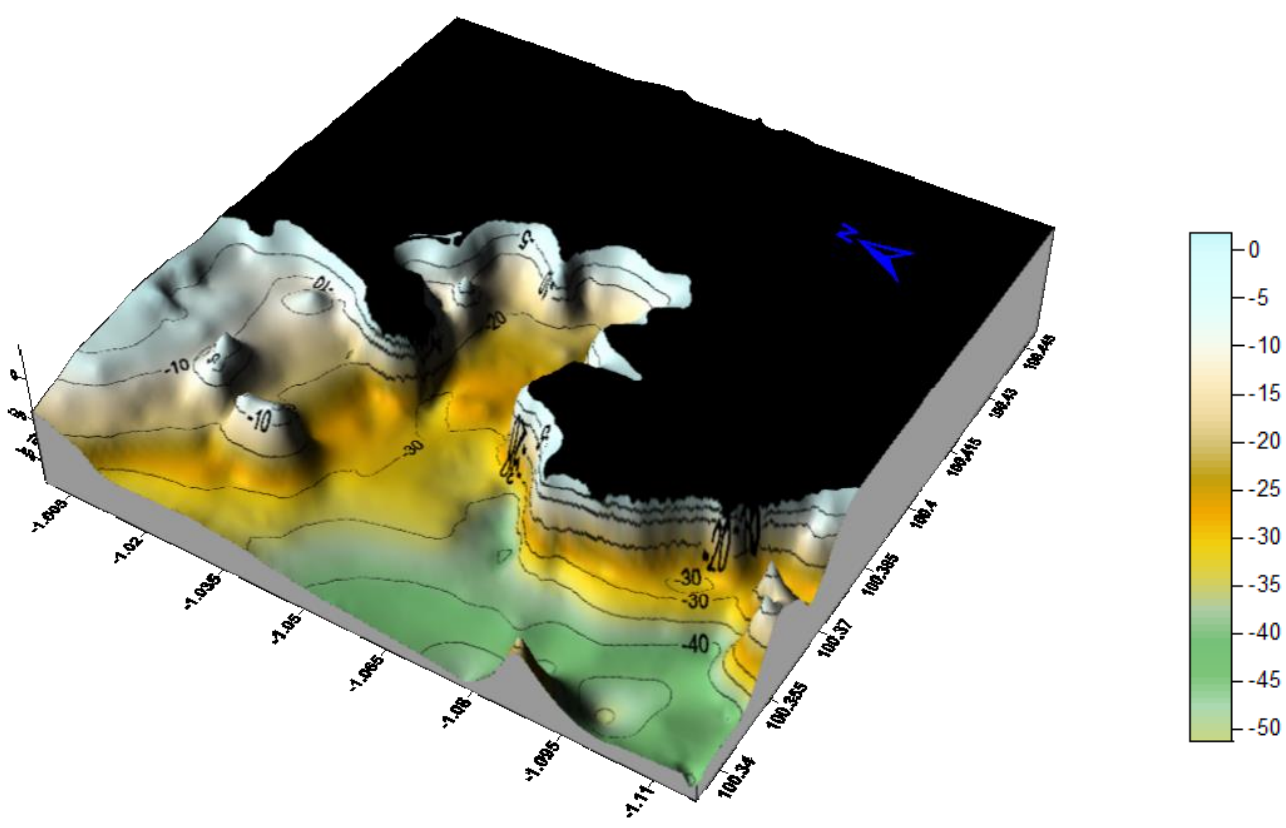

Gambar 2. Peta 3D batimetri perairan Teluk Bungus dan sekitarnya 
Sebagai pembanding hasil pengolahan dari data bathimetri Dishidros tersebut, juga ditampilkan peta $3 D$ hasil pengukuran yang

dilakukan oleh Yulius et al. (2000), pada Gambar 3.

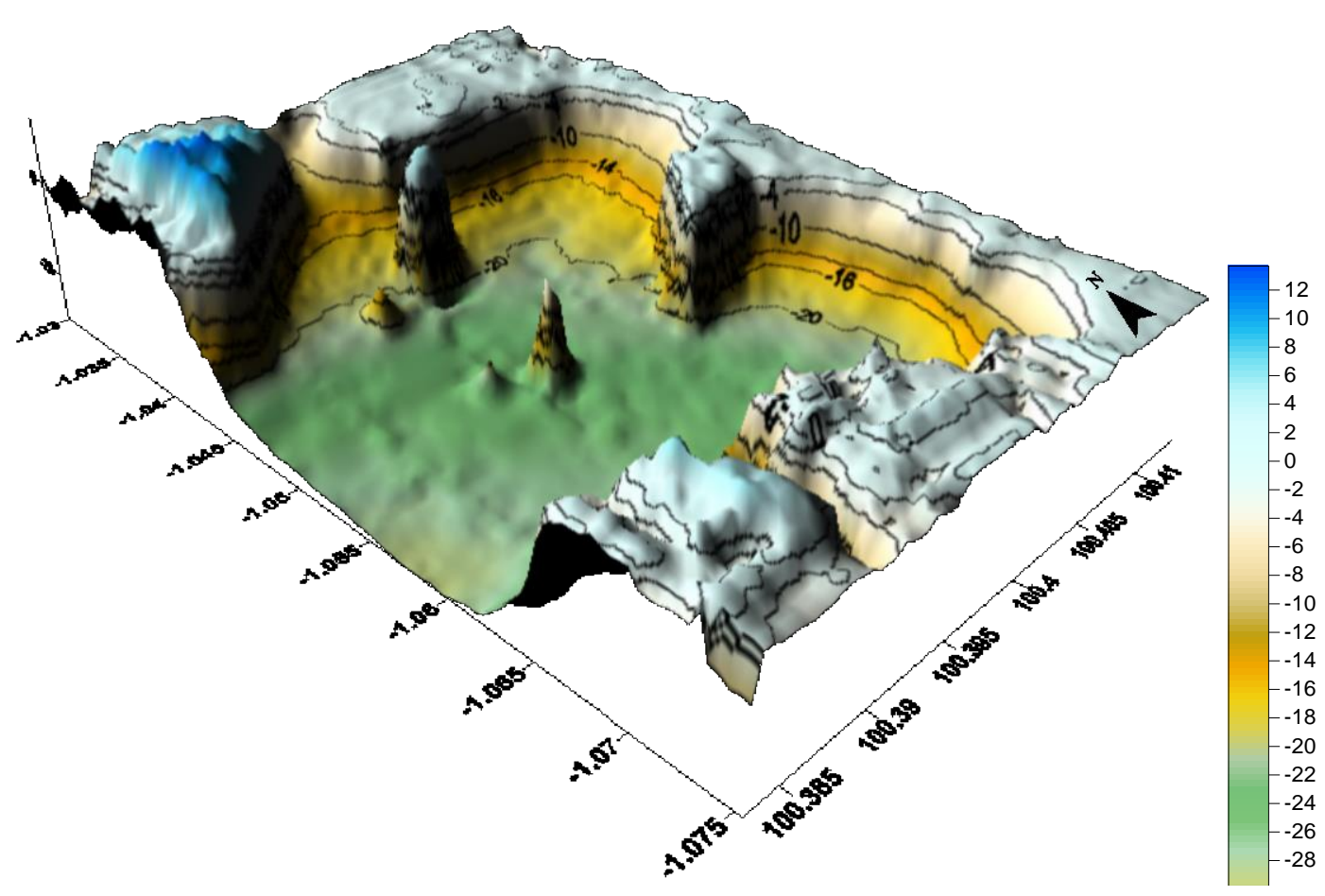

Gambar 3. Peta 3D batimetri perairan Teluk Bungus dan sekitarnya (Yulius et al., 2010)

Perairan Teluk Bungus yang berhadapan langsung dengan laut lepas (Samudera Hindia), dapat berpengaruh pada bentuk relief dasar laut yang tidak beraturan. Hal ini tidak terlihat dampak yang signifikan, karena perairannya cukup terlindungi oleh bentuk teluk. Pengaruh samudera yang cukup terlihat adalah bentuk lerengnya terjal, memiliki slope atau kemiringan yang drastis (Gambar 2 dan Gambar 3). Namun kondisi ini hanya terlihat sampai kedalaman 20 meter, yang masih berada dekat dengan pinggir garis pantai. Setelah kedalaman tersebut, bentuk lereng dasar laut Teluk Bungus terjadi penurunan yang cukup kecil. Dan juga, tidak terlihat bentuk relief dasar laut Teluk Bungus yang curam.

\section{Pasang Surut}

Grafik pasang surut laut perairan Teluk Bungus dibuat berdasarkan nilai surut terendah pada rentang waktu pengukuran. Jenis pasang surut yang terjadi adalah tipe campuran (Mixed Tide), terjadi 2 kali pasang dan 2 kali surut dalam satu hari namun dengan bentuk pasang surut pertama berbeda dengan pasang surut ke dua. Hal ini dapat dilihat dari hasil grafik pasang surut Teluk Bungus berikut yang terukur dari alat ukur arus $A D C P$ (Gambar 4). Dari data tinggi muka laut tersebut, sehingga diperoleh nilai kisaran pasang surut (tunggang pasut) sebesar 139,30 cm.

Analisis Admiralty yang dilakukan adalah dengan menggunakan pengamatan 29 hari, karena cukup banyak data yang tersedia. Waktu pengamatan yang diambil untuk analisis ini adalah data pada tanggal 15 Oktober - 12 November 2013. Tabel 1 merupakan komponen pasang surut yang diperoleh dari analisis Admiralty.

Dengan nilai komponen pasang surut yang dihasilkan tersebut (Tabel 1), maka dapat ditentukan nilai bilang Formzahl, yaitu sebesar 0,3976. Dapat diketahui secara pasti tipe pasang surut yang terjadi pada perairan Teluk Bungus, yaitu tipe campuran condong semidiurnal $(0,25 \leq F \leq 1,5)$. Untuk elevasi penting tinggi muka air yang diperoleh adalah seperti Gambar 5. 


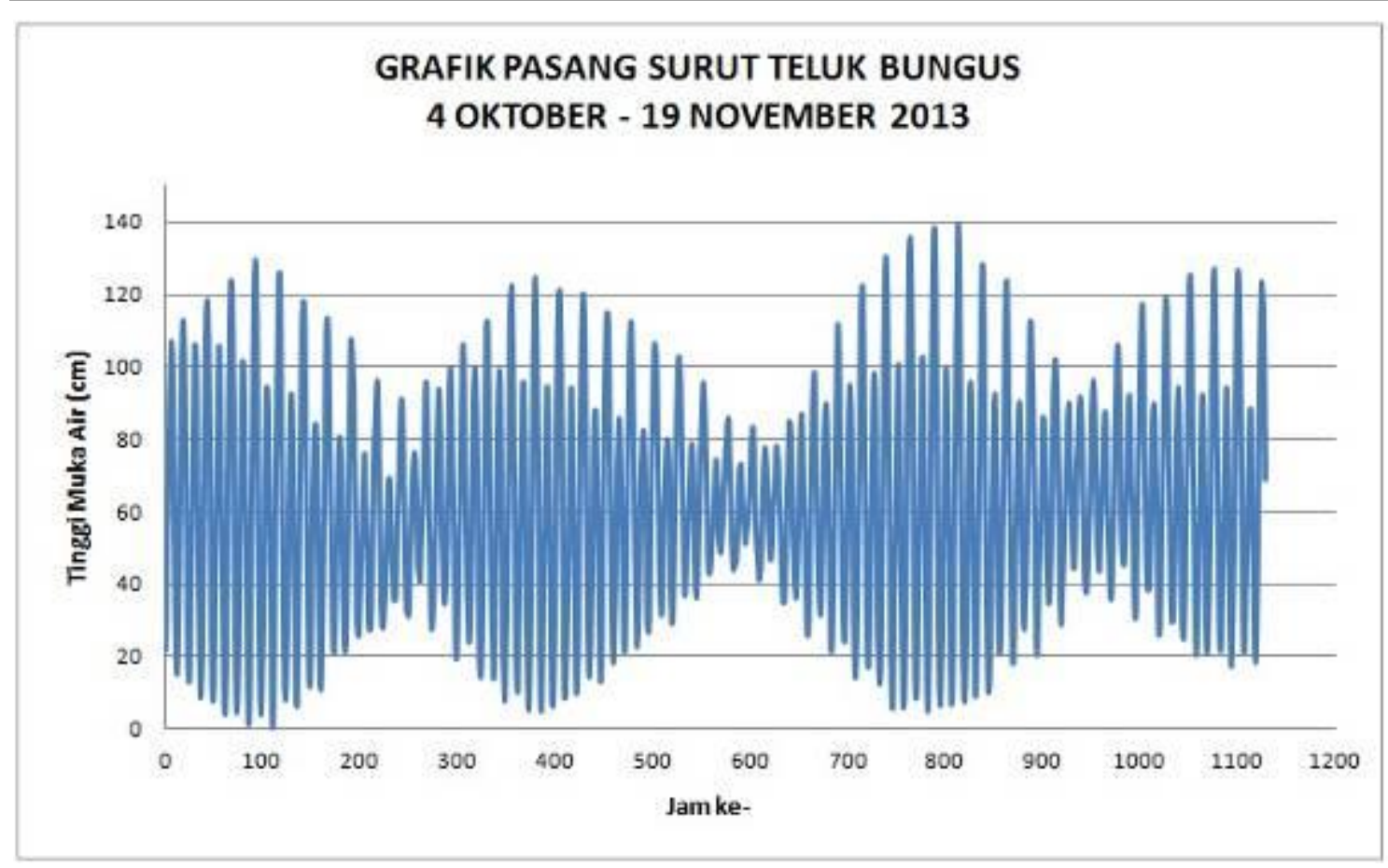

Gambar 4. Pasang surut laut perairan Teluk Bungus

Tabel 1. Komponen pasang surut perairan Teluk Bungus

\begin{tabular}{ccccccccccc}
\hline & S0 & M2 & S2 & N2 & K1 & 01 & M4 & MS4 & K2 & P1 \\
\cline { 2 - 10 } & & & & & & & & & & \\
$\mathbf{A}(\mathbf{c m})$ & 61.55 & 35.21 & 14.46 & 8.01 & 12.25 & 7.50 & 1.61 & 0.60 & 3.90 & 4.04 \\
$\mathbf{g}^{\circ}$ & & 180.05 & 231.74 & 160.69 & 276.18 & 266.19 & 80.57 & 217.64 & 231.74 & 276.18 \\
\hline
\end{tabular}

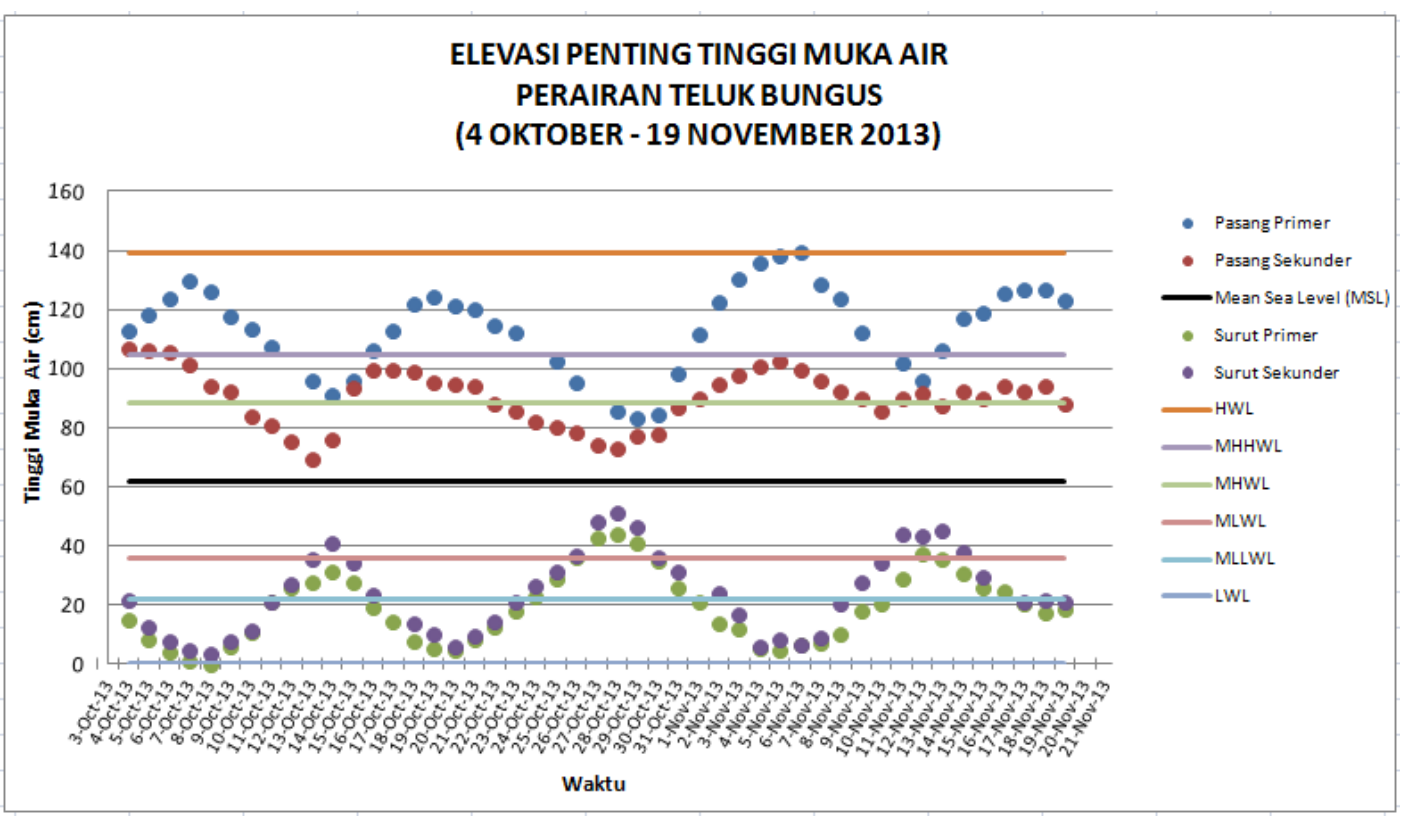

Gambar 5. Elevasi penting tinggi muka air perairan Teluk Bungus 
Dari nilai elevasi penting muka air tersebut, dapat ditentukan dan terlihat kondisi pasang purnama terjadi pada Tanggal 8 Oktober, 20 Oktober, 5 November dan 18 November 2013. Waktu-waktu tersebut merupakan awal bulan baru (8 Oktober dan 5 November 2013) dan bulan purnama (20 Oktober dan 18 November 2013) dari penanggalan kalender lunar. Pada saat tersebut terjadi pasang tinggi (pasang primer) yang paling tinggi dan surut primer yang sangat rendah (Modifikasi dari Surbakti, 2007).

Sedangkan kejadian pasang perbani terjadi pada tanggal 13 dan 28 Oktober 2013 (1/4 kuartal pertama), serta 11 November 2013 (1/4 kuartal terakhir) dari penanggalan kalender lunar. Pada kejadian pasang perbani ini, terjadi pasang sekunder yang paling rendah dan surut sekunder yang tertinggi (Modifikasi dari Surbakti, 2007). Namun kejadian pasang perbani tanggal 13 Oktober 2013 tidak terjadi surut sekunder yang tertinggi, dan tanggal 11 November 2013 juga tidak terjadi pasang sekunder yang paling rendah.

Untuk nilai elevasi penting muka air lainnya adalah MSL (mean sea level) sebesar $61,69 \mathrm{~cm}, \mathrm{MLWL}$ (mean low water level) $35,89 \mathrm{~cm}$, MLLWL (mean lower low water level) $22,11 \mathrm{~cm}$, MHWL (mean high water level) 88,32 dan MHHWL (mean higher high water level) sebesar $104,58 \mathrm{~cm}$.

\section{Gelombang}

Gelombang yang terjadi pada wilayah sekitar perairan Teluk Bungus berupa tinggi gelombang signifikan, dengan interval waktu perekaman data 6 jam. Gambar 6 merupakan hasil pengolahan data gelombang laut perairan Teluk Bungus dan sekitarnya.

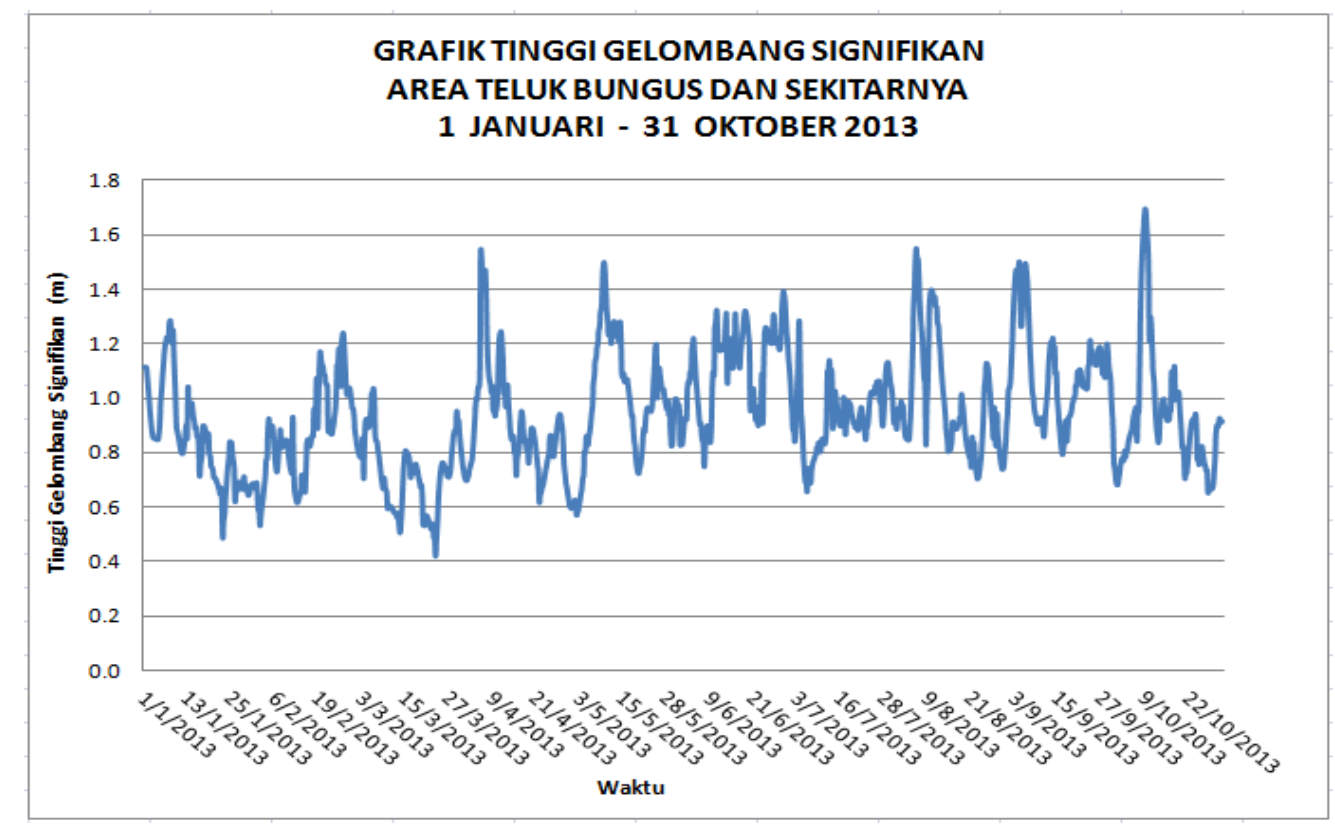

Gambar 6. Tinggi gelombang signifikan perairan Teluk Bungus dan sekitarnya

Gelombang yang terjadi di perairan Teluk Bungus dan sekitarnya pada bulan Januari Oktober 2013 memiliki tinggi gelombang dengan kisaran 0,42 $\mathrm{m}$ sampai $1,7 \mathrm{~m}$ (Gambar 6). Kisaran tinggi gelombang cukup besar terjadi pada bulan Oktober 2013 dengan kisaran 0,65 - 1,7 m, terutama tanggal 9 Oktober hingga 11 Oktober 2013 dengan tinggi gelombang 1,5 - 1,7 m (Gambar 7). Namun, kejadian gelombang cukup besar ini tidak dipengaruhi oleh faktor angin di daratan yang tercatat pada stasiun Automatic Weather System Bukit Lampu Bungus. Asumsi ini dapat diperkuat dari nilai data angin pada saat terjadinya gelombang besar tersebut, angin di daratan masih 
berkisar rendah (sepoi-sepoi) sampai sedang (Laporan Tahunan 2013 - Kegiatan di Bungus). Hal ini dapat terjadi karena tinggi gelombang signifikan yang terukur berada pada laut lepas pantai, sedangkan angin yang terukur masih berada dekat dengan pantai yang hanya bisa membangkitkan gelombang di dalam kawasan Teluk Bungus.

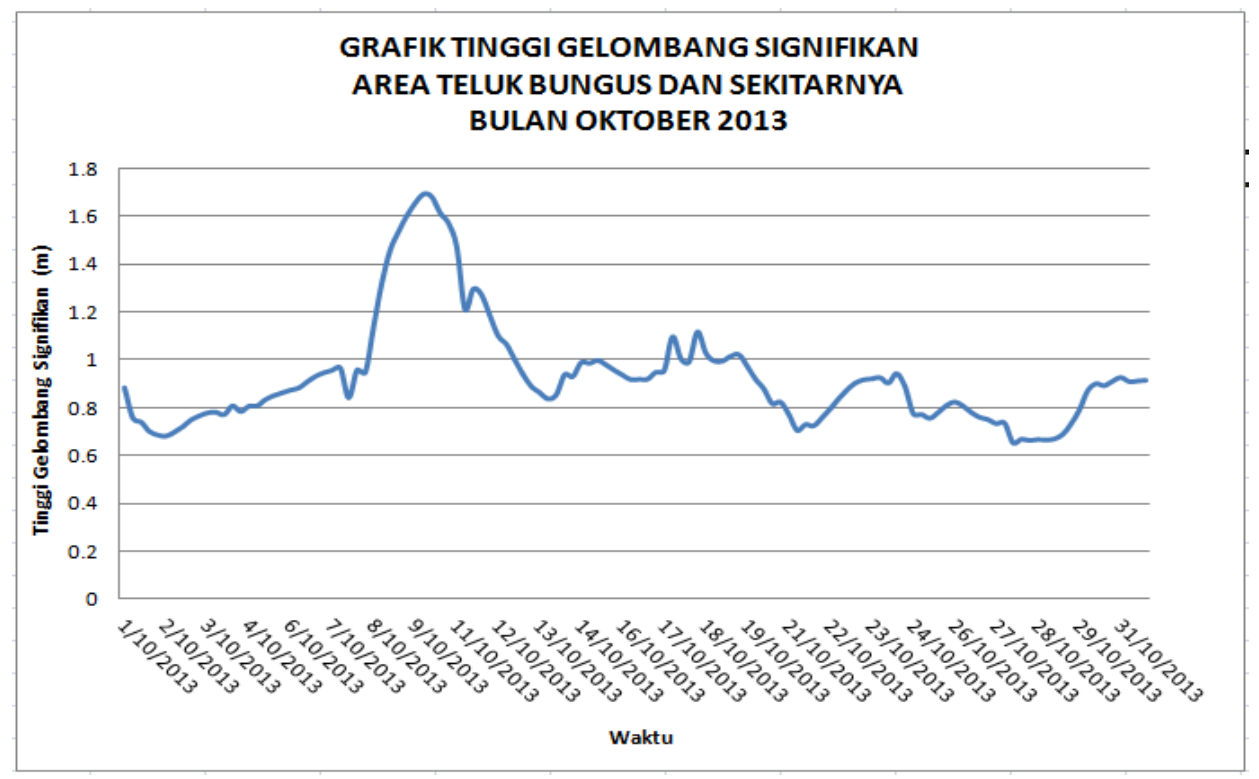

Gambar 7. Tinggi gelombang signifikan perairan Teluk Bungus (Oktober 2013)

Sedangkan kondisi gelombang laut di perairan Sumatera Barat pada Bulan Agustus hingga Desember 2015, dapat terlihat dari grafik peramalan/model tinggi gelombang signifikan (Gambar 8).

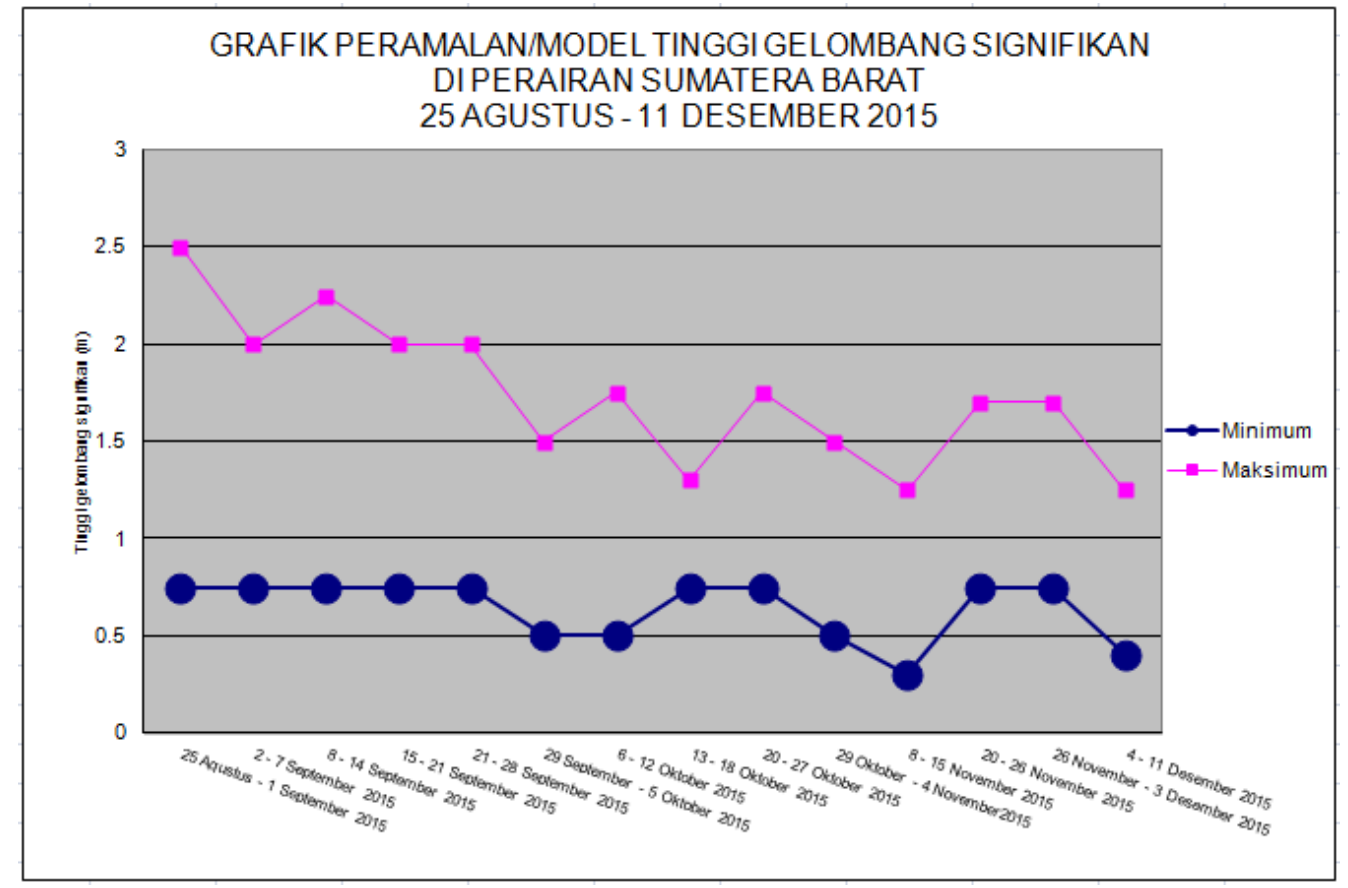

Gambar 8. Tinggi gelombang signifikan perairan Sumatera Barat (BMKG, 2015) 
Kondisi gelombang laut perairan Sumatera Barat sedikit lebih tinggi dibandingkan dengan data tahun 2013, yang umumnya berlokasi dekat perairan Teluk Bungus. Kisaran tinggi gelombang siginifikan perairan ini adalah sebesar 0,3 - 2,5 m (Gambar 8).

\section{Arus Laut}

Hasil pengolahan data arus kedalaman 10,5 m di perairan Teluk Bungus adalah seperti terlihat pada Gambar 9, 10, dan 11.

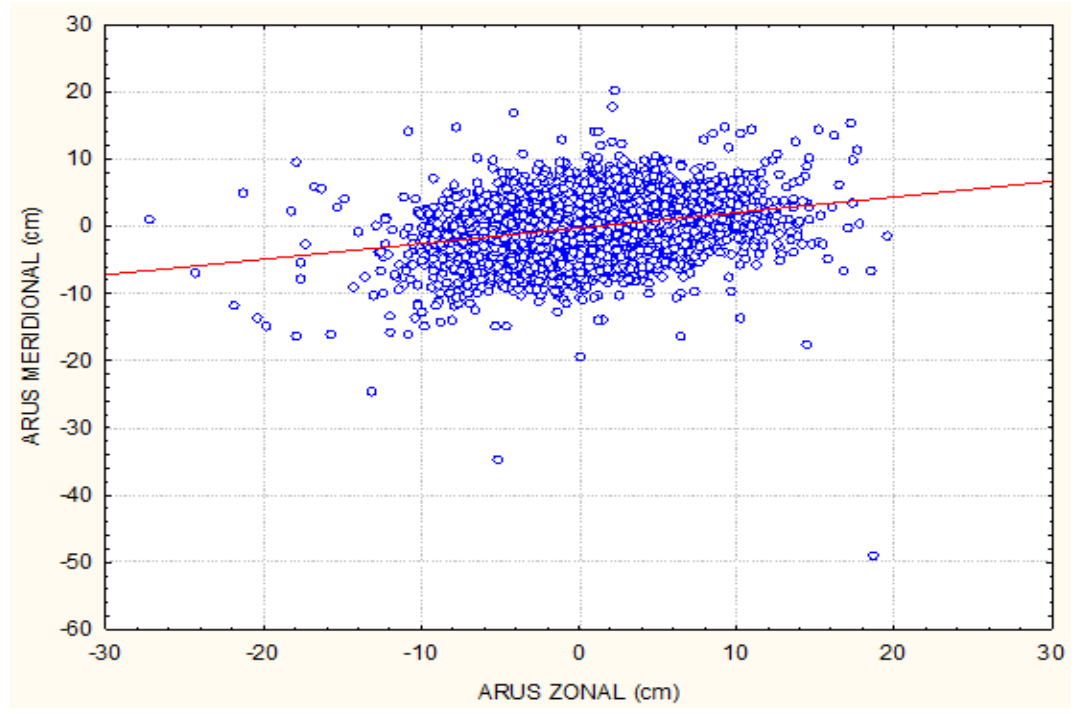

Gambar 9. Grafik scatterplot arus $10.5 \mathrm{~m}$ perairan Teluk Bungus

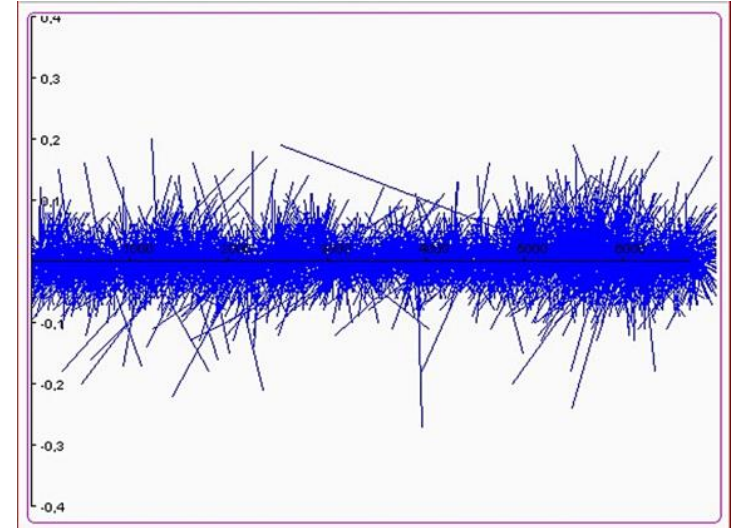

Gambar 10. Stick diagram komponen kecepatan arus kedalaman 10,5 meter

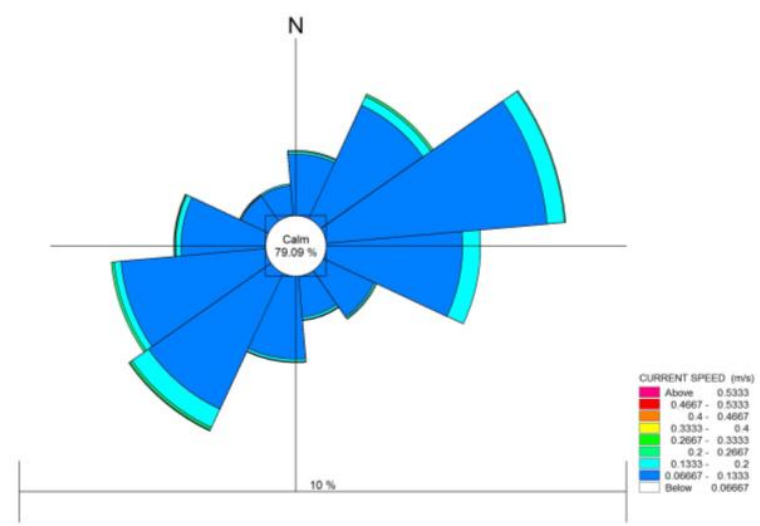

Gambar 11. Arah pergerakan arus dominan kedalaman 10,5 meter
Kecepatan rata-rata arus kedalaman 10,5 $\mathrm{m}$ perairan Teluk Bungus dari tanggal 3 Oktober 2013 pukul 15.00 WIB sampai 20 November 2013 pukul 00.20 WIB adalah sebesar $4,77 \mathrm{~cm} / \mathrm{s}$, terjadi arus cukup besar $52,40 \mathrm{~cm} / \mathrm{s}$ tanggal 11 November 2013 pukul 14.50 WIB dengan arah tenggaraselatan. Dari pengolahan data dalam bentuk scatter plot (Gambar 9) dan stick diagram (Gambar 10) terlihat bahwa komponen kecepatan arus saling mendukung dalam pergerakan arah dan kecepatan arus, dalam hal ini adalah East Velocity (U) dan North Veocity (V). Arus di wilayah permukaan pergerakannya dipengaruhi oleh beberapa faktor, menurut Wisha et al. (2015) menyatakan bahwa kecepatan arus secara vertikal dipegaruhi oleh angin, pasang surut, densitas, dan tahanan dasar. Dinamika arus dipermukaan ini berpengaruh terhadap distribusi zat-zat terlarut di perairan Teluk Bungus, Hoekstra et al. (2002) menyatakan bahwa drift current dipermukaan dipengaruhi oleh 
angin muson dan menyebabkan pengangkutan partikel tersuspensi yang tinggi di wilayah Teluk Bungus.

Untuk kecepatan rata-rata harian arus permukaan berkisar antara $3.58-6.13 \mathrm{~cm} / \mathrm{s}$ dengan arah arus rata-rata menuju selatan $\left(168.39^{\circ}\right)$. Arah arus dominan (Gambar 11) terjadi ke arah timur laut-timur (menuju ke arah daratan), sehingga dapat mempengaruhi terjadinya akresi pada beberapa lokasi pesisir di wilayah Teluk Bungus. Hal ini dapat terlihat pada daerah Pantai Sako pada bulan Oktober hingga November 2013 dengan bertambahnya pesisir pantai tersebut. Kejadian arus ini

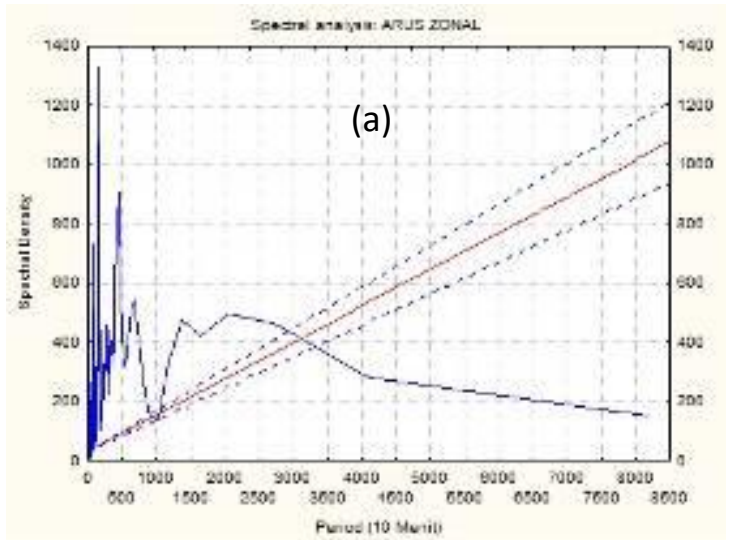

terjadi pada tanggal 20, 23 dan 29 Oktober 2013, serta tanggal 20 November 2013. Namun dominansi arus juga terlihat ke arah barat daya (menuju laut), yang menyebabkan pada saat-saat tertentu pada pesisir pantai sekitar teluk bungus terjadi abrasi yang cukup parah.

Hasil pengolahan data arus (Gambar 12), terlihat kejadian arus di dominasi oleh pengaruh arus zonal, yaitu arah arus umumnya ke arah timur atau barat. Asumsi tersebut juga didukung dengan hasil analisis spektral yang dilakukan. Berikut hasil pengolahan data arus dengan analisis spektral.

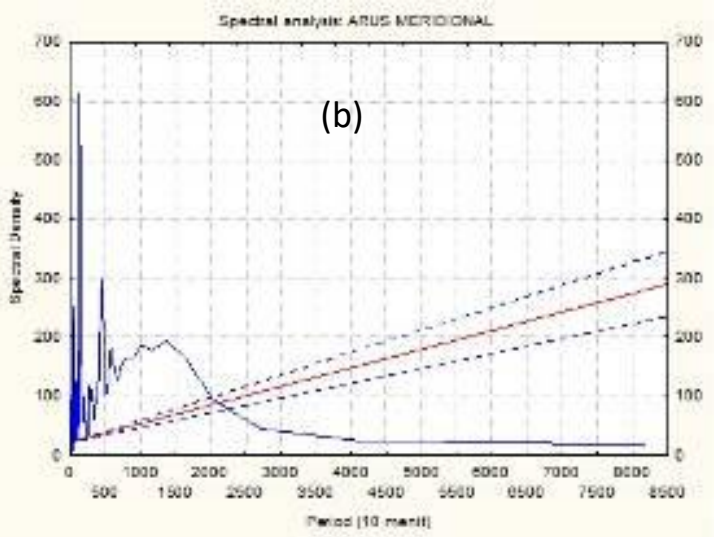

Gambar 12. Grafik Spectral Density Arus, (a) arus zonal, (b) arus meridional

Dari hasil analisis arus tersebut, nilai spektrum density arus tertinggi pada komponen timur - barat adalah 1326,29 $\left((\mathrm{cm} / \mathrm{s})^{2}\right) /$ C.P.D $), \quad$ dan $\quad 614.19$ $\left((\mathrm{cm} / \mathrm{s})^{2}\right) /$ C.P.D) untuk nilai spektrum density arus tertinggi pada komponen utara - selatan. Dari nilai yang diperoleh tersebut sangat terlihat jelas bahwa arus zonal jauh lebih berpengaruh pada perairan Teluk Bungus.

Pada kedalaman 18,5 m, hasil pengolahan data arus di perairan Teluk Bungus adalah sebagai berikut (Gambar 13).

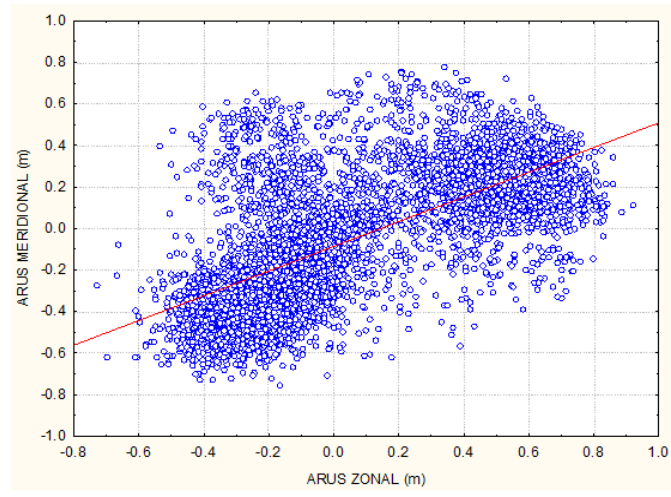

Gambar 13. Grafik scatterplot arus 18.5m perairan Teluk Bungus 


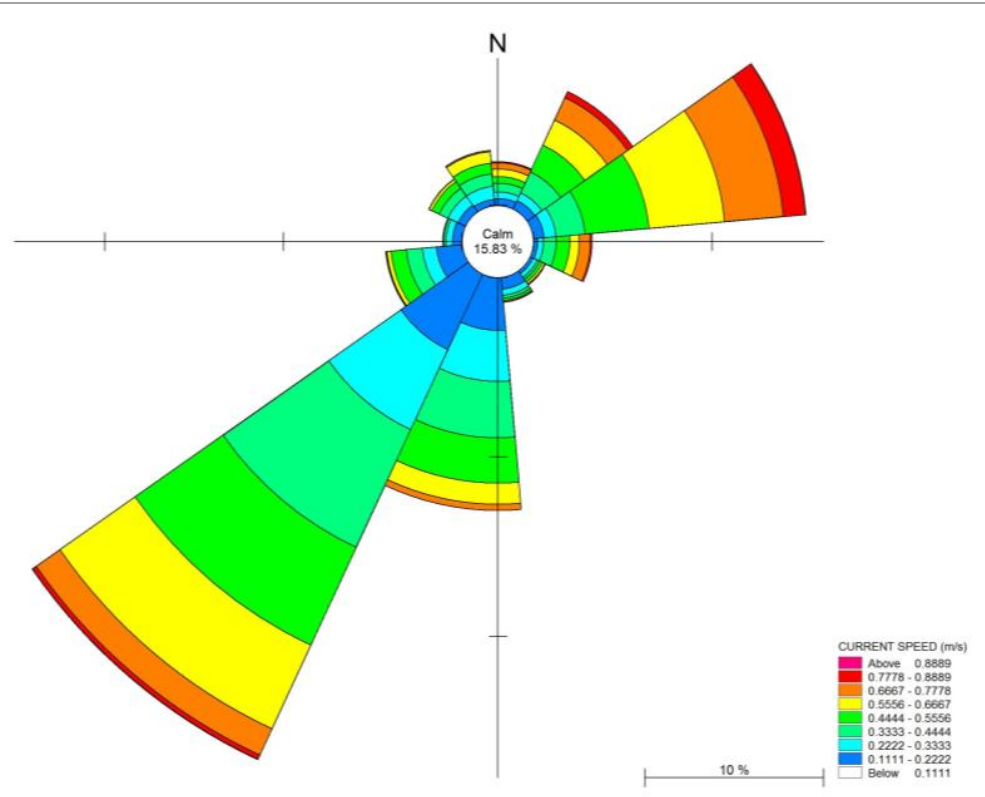

Gambar 14. Arah pegerakan arus dominan kedalaman 18,5 meter

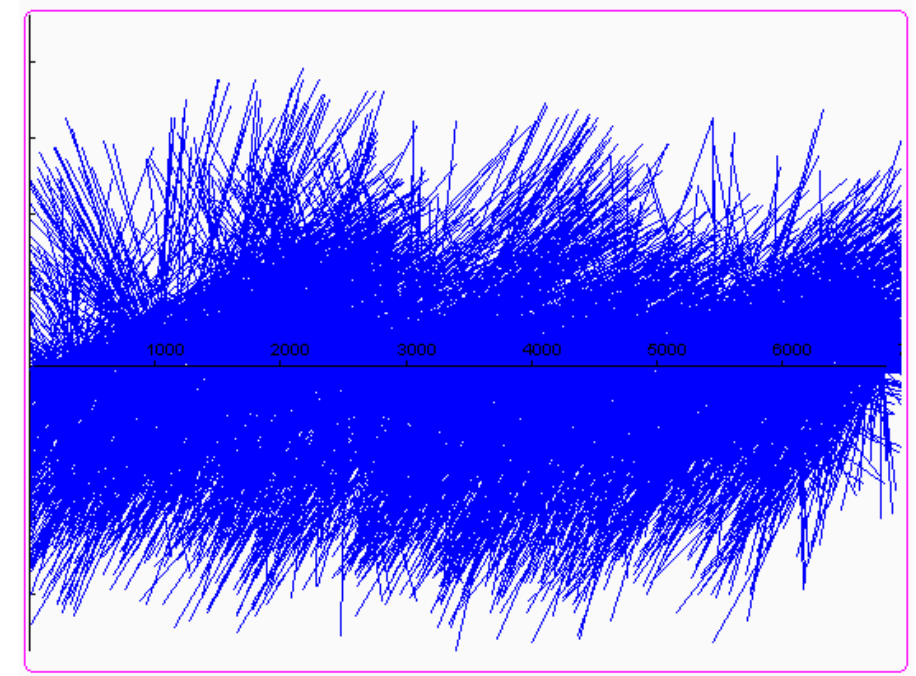

Gambar 15. Stick Diagram komponen kecepatan arus kedalaman 18,5 meter

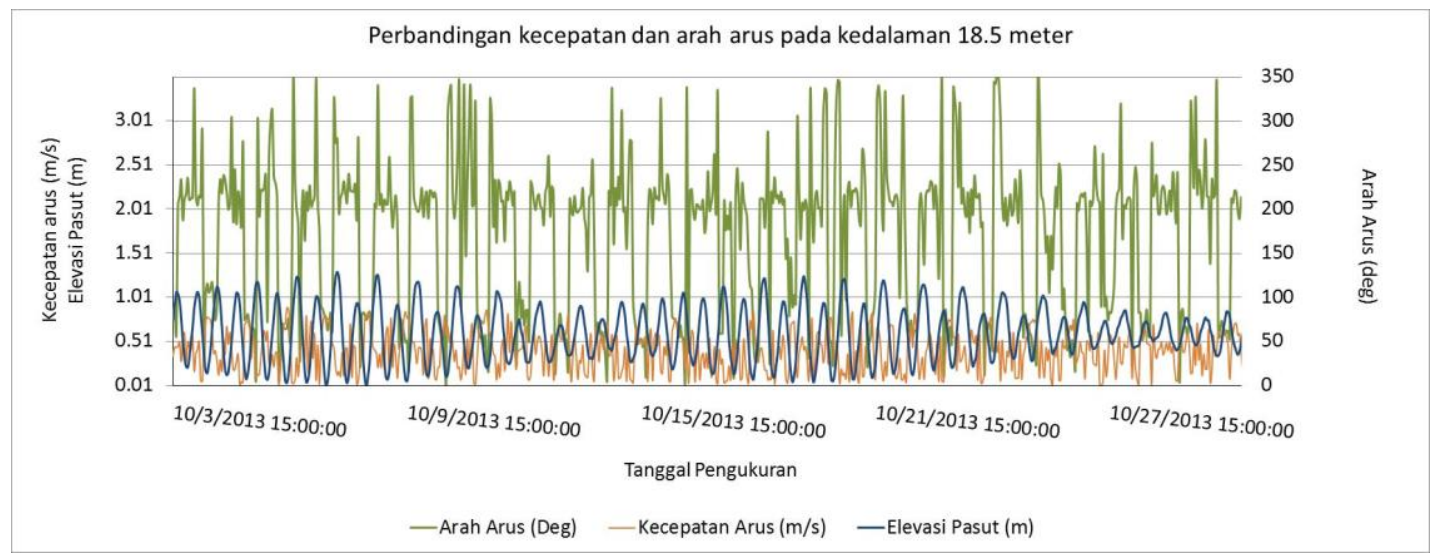

Gambar 16. Perbandingan arah, kecepatan arus dengan pasang surut 
Terlihat sedikit perbedaan arah dan kecepatan arus pada kedalaman 18,5 m dengan arus pada permukaan. Kecepatan arus pada kedalaman ini lebih tinggi dibandingkan dengan arus permukaan. Kecepatan rata-rata arus yang terjadi pada kedalaman ini adalah sebesar $37,99 \mathrm{~cm} / \mathrm{s}$, dengan kisaran kecepatan rata-rata harian sebesar $24,24-47,13 \mathrm{~cm} / \mathrm{s}$. Hal tersebut terjadi karena pada kedalaman $18,5 \mathrm{~m}$, arus laut dapat dipengaruhi / dibangkitkan oleh kedalaman (gradien densitas) dan suhu. Semakin dalam air laut, arus laut dapat semakin bertambah besar. Sedangkan arah arus rata-rata harian pada kedalaman ini dari tanggal 3 Oktober - 20 November 2013 adalah sebesar 172,94 ${ }^{\circ}$ (arah menuju selatan).

Dari hasil scatter plot (Gambar 13) dan stick diagram (Gambar 15) terlihat bahwa pola arus lebih acak dengan kecepatan yang lebih tinggi dibandingkan dengan kecepatan arus dipermukaan. Hal ini disebabkan karena adanya perubahan densitas di wilayah dasar perairan sehingga arus bergerak dari densitas tinggi dan densitas rendah, dengan kecepatan yang lebih tinggi dari pada arus permukaan, anomali ini dapat menyebabkan tingginya turbulensi dasar perairan sehingga terjadi peningkatan sedimen tersuspensi di kolom perairan, yang akhirnya menimbulkan pendangkalan di beberapa wilayah perairan Teluk Bungus karena mekanisme transport

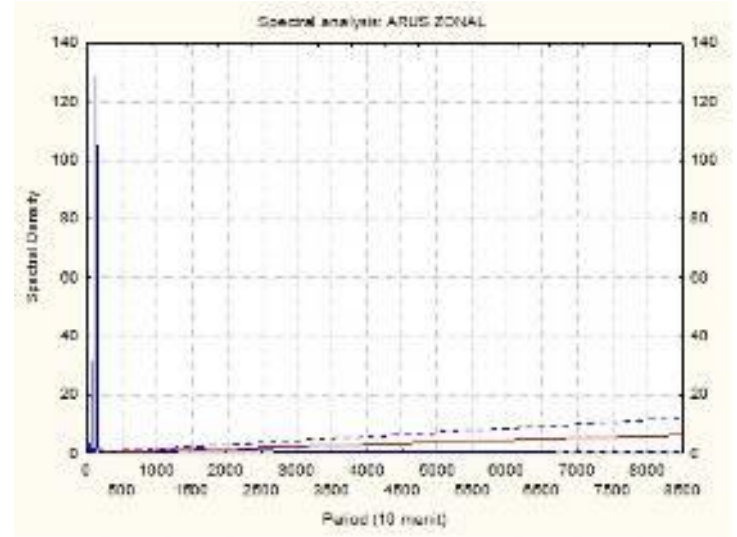

(a) yang lemah di permukaan. Menurut Nugroho dan Anugroho (2007) meyatakan bahwa pola arus di Teluk Bungus tergolong arus lemah karena sudah banyak terdeformasi dibagian mulut teluk, sehingga mekanisme transport yang terjadi menjadi kecil dan menimbulkan pendangkalan di beberapa wilayah Teluk Bungus. Untuk dominansi arah arus masih ke arah barat daya dan juga timur laut-timur (Gambar 14), hampir sama seperti halnya arus pada permukaan.

Pergerakan arus diperairan Teluk bungus juga dipengaruhi oleh pasang surut (Gambar 16), dan arah arus masih dipengaruhi oleh angin dan gelombang. Hal terebut menunjukkan bahwa banyak sekali faktor dan gaya pembangkit arus di perairan teluk dan didominasi oleh arus pasang surut, perubahan pasang dan surut air laut merupakan faktor utama pembangkit arus (tide dominated). Hal tersebut sesuai, menurut Wisha et al. (2015) bahwa diperairan teluk, pembangkitan arus didominasi oleh gaya pasang surut, sehingga di wilayah tersebut didominasi oleh arus pasut, terutama dibagian muara sungai yang dapat terlihat jelas pengaruh arus pasang surutnya.

Sama seperti arus pada permukaan, arus kedalaman 18,5 $\mathrm{m}$ juga didominasi oleh arus zonal. Berikut hasil analisis spektrum arus yang dilakukan (Gambar 17).

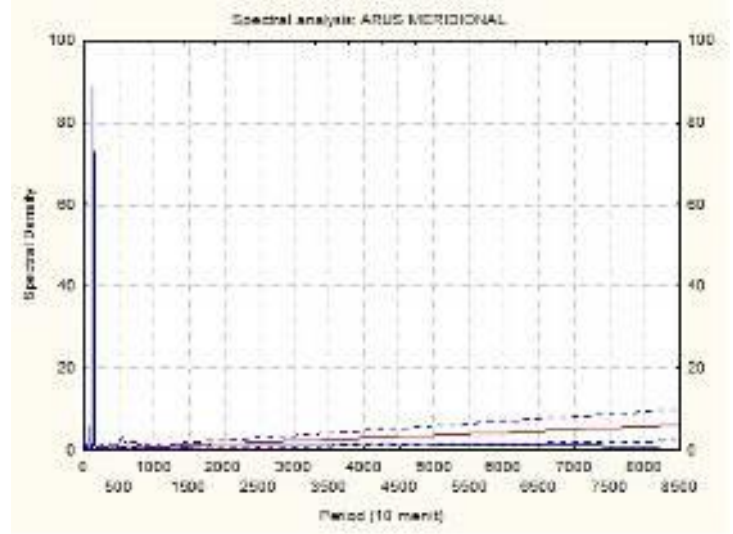

(b)

Gambar 17. Grafik Spectral Density Arus, (a) arus zonal, (b) arus meridional

Nilai spektrum density arus tertinggi pada komponen timur - barat (kedalaman 18,5 m) adalah $128,49\left((\mathrm{~m} / \mathrm{s})^{2}\right) /$ C.P.D $)$, dan 88,80 $\left((\mathrm{m} / \mathrm{s})^{2}\right) /$ C.P.D) untuk nilai spektrum density arus tertinggi pada komponen utara - selatan. Nilai spektrum density arus komponen timur - barat jauh lebih tinggi dari komponen utara - selatan, yang dapat menunjukkan dominasi arus zonal tersebut. 


\section{KESIMPULAN DAN SARAN}

1. Kedalaman laut Teluk Bungus tergolong dangkal, yaitu $\leq 30 \mathrm{~m}$. Perairannya terlindungi oleh bentuk teluk, bentuk relief dasar laut tidak ada pengaruh dari samudera.

2. Pasang surut yang terjadi adalah tipe campuran dominan ganda (Mixed Tide, Prevailing Semidiurnal), tunggang pasut sebesar $139.30 \mathrm{~cm}$. Pasang purnama terjadi pada tanggal 7 Oktober, 19 Oktober, 5 November dan 18 November 2013, sedangkan pasang perbani terjadi Tanggal 13 dan 28 Oktober, serta 11 November 2013.

3. Gelombang signifikan sekitar perairan Teluk Bungus (Januari - Oktober 2013) sebesar 0,42 - 1,7 m dan 0,3 - 2,5 m (Agustus - Desember 2015).

4. Arus laut perairan Teluk Bungus dipengaruhi arus zonal. Kecepatan rata-rata arus permukaan sebesar $0,0477 \mathrm{~m} / \mathrm{s}$, terjadi arus cukup besar $0,5240 \mathrm{~m} / \mathrm{s}$ (arah tenggara - selatan). Pada kedalaman 18,5 m, kecepatan arus rata-rata $0,3799 \mathrm{~m} / \mathrm{s}$ dan arus maksimum $0,9320 \mathrm{~m} / \mathrm{s}$ dengan arah barat daya).

\section{UCAPAN TERIMA KASIH}

Ucapan terimakasih kami sampaikan kepada Kepala LPSDKP KKP Bungus atas dukungannya dalam pelaksanaan kegiatan ini. Terimaksih juga kepada Ketua Kelti Kerentanan Pesisir LPSDKP, atas arahan dan ide awalnya terhadap kegiatan penelitian. Serta kepada teman-teman yang membantu terlaksananya seluruh kegiatan penelitian sampai selesai.

\section{DAFTAR PUSTAKA}

Anonim. (2007). Air Laut yang Selalu Bergerak. Bali Post Online. http://www.balipost.co.id/balipostcet ak/2007/1/15/l2.htm. [Akses Bulan Maret 2007].

Ariana, K. D. (2002). Pemetaan Batimetri dan Karakteristik Dasar Perairan Dangkal di Perairan Pulau Dangar Provinsi NTB dengan Data Satelit Penginderaan Jauh. Skripsi. Institut Pertanian Bogor. Bogor. $57 \mathrm{hlm}$.

Bakosurtanal. (2007). Prediksi Pasang Surut 2008. Bidang Medan Gayaberat dan
Pasang Surut, Pusat Geodesi dan Geodinamika: Cibinong. $418 \mathrm{hlm}$.

Dishidros. (2006). Peta Bathymetri Sumatera - Pantai Barat "Pariaman hingga Pulau Nyamuk". Cetakan ke $\mathrm{V}$ 2006. Koreksi BPI No.24 Tahun 2011.

ECMWF. Data Gelombang Signifikan. http://apps.ecmwf.int/datasets/. [Akses Tanggal 3 Februari 2013].

Fadilah, Suripin, \& Sasongko, D. P. (2014). Menentukan Tipe Pasang Surut dan Muka Air Rencana Perairan Laut Kab. Bengkulu Tengah Menggunakan Metode Admiralty. Maspari journal, 6(1), 1-12.

Hoekstra, P., Lindeboom, H., Bak, R., Bergh, G. V. D., Tiwi, D. A., Kiswara, W., Meesters, E., Noor, Y., Sukmantalya, N., Nuraini, S., \& Weering, T.V. (2002). An Integrated Coastal Zone Management Study. Staple (Ed.) Scietific Programme Indonesia-Netherlands Procesings of a workshop held on February 12th 2002. Bandung. Indonesia. p: 59-70.

Kurniawan, R., Habibie, M. N., \& Suratno (2011). Variasi Bulanan Gelombang Laut di Indonesia. Jurnal Meteorologi dan Geofisika, 12(3), 221-232.

LPSDKP - Badan Litbang KKP. (2014). Laporan Tahunan: Kerentanan Ekosistem Kawasan Teluk Bungus terhadap Perubahan Tata Guna Lahan. Bungus. Padang. $131 \mathrm{hlm}$.

Nugroho, D. S., \& Anugroho, A. (2007). Studi Pola Sirkulasi Arus Laut di Perairan Pantai Provinsi Sumatra Barat. IImu Kelautan. 12(2), 79-92.

Poerbandono (2004). Pemecah Ombak Timbulkan Masalah Baru. Bandung. http://www.pikiran-

rakyat.com/cetak/0604/10/cakrawala /lainnya06.htm. [Akses Bulan April 2007].

NOAA. (2016). Tidal Datums. https://tidesandcurrents.noaa.gov/da tum_options.html [Akses Tanggal 2 April 2016].

Samskerta, I. P., Bachtiar, H., \& Riandini, F. (2011). Perubahan Karakteristik Pola Arus Laut Bali Terkait Kejadian ENSO. Kolokium Pusat Penelitian dan Pengembangan Sumber Daya Air. 12 hlm. 
Silalahi, S. http://www.academia.edu/ 7203382/Modul_1_Admiralty. [Akses Tanggal 14 November 2013].

Stewart, R. H. (2008). Introduction to Physical Oceanography. Department of Oceanography. Texas A \& M University. $345 \mathrm{hlm}$.

Surbakti, H. (2007). Pasang Surut. https://surbakti77.wordpress.com/20 07/09/03/pasang-surut/. [Akses Tanggal 18 Juni 2015].

Sudjono, Evie, H., Setiawan, A., Hadi, S., \& Ningsih, N. S. (2011). Studi Komponen Pasang Surut Perairan Dangkal (Over and Compound Tides) Model Kanal 1 Dimensi Dengan Menggunakan Metoda Asimilasi Data Variasional. Jurnal ITKT, 3(1), 1-12.

Tanto, T. (2009). Kinerja OTT PS 1 Sebagai Alat Pengukur Pasang Surut Air
Laut di Muara Binuangeun, Provinsi Banten. Skripsi. Institut Pertanian Bogor. Bogor. $84 \mathrm{hlm}$.

Wisha, U. J., Husrin, S., \& Prihantono, J. (2015). Hydrodynamics Banten Bay During Transitional seasons (August-September). J. IImu Kelautan, 20(2), 101-112.

Wyrtki, K. (1961). Physical Oceanography of the Southeast Asian Waters. Naga Report Volume 2. The University of California Scripps Institution of Oceanography La Jolla: California. $195 \mathrm{hlm}$.

Yulius, Prihatno, H. \& Suhelmi, I. R. (2010). Pola Spasial Kedalaman Perairan di Teluk Bungus, Kota Padang. Prosiding Ikatan Sarjana Oseanologi Indonesia (ISOI), hal. 205-212. 